\title{
Hybrid Organizations: A Systematic Review of the Current Literature
}

\author{
Silvana Secinaro ${ }^{1}$, Luigi Corvo ${ }^{2}$, Valerio Brescia ${ }^{1} \&$ Daniel Iannaci $^{1}$ \\ ${ }^{1}$ Department of Management, University of Turin, Italy \\ ${ }^{2}$ Department of Management and Law, University of Roma "Tor Vergata", Italy \\ Correspondence: Daniel Iannaci, Department of Management, University of Turin, Corso Unione Sovietica \\ 218bis, Turin, 10134, Italy.
}

Received: June 26, 2019

Accepted: August 2, 2019

Online Published: September 30, 2019

doi:10.5539/ibr.v12n11p1

URL: https://doi.org/10.5539/ibr.v12n11p1

\begin{abstract}
The purpose of this paper is to systematically review literature concerning hybrid structures, that is, structures that are used to implement various forms of management. More specifically, the authors aim to answer two questions: can the evolution of hybrid organizations be analyzed and mapped, and if so, what are the factors that govern their development?

The document is based on a systematic review approach of Little et al. (2009), which aims to make the selection of literature and the review process transparent and replicable following steps, eliminating the problem of prejudice to ensure objectivity of the research and credibility in the results as demonstrated by Rosenthal (1979) and Cooper (2003).

What emerges from the literature of hybrid organizations seen from the point of view of NPM, the concept of Paradox, PPPs and Hybrid Impact is very interesting because by tidying up the concepts that various scholars have found it is possible to define what have been the factors that influenced the evolution of hybrid organizations giving a historical definition and helping to understand the roots of the concept and specifically where these new entities will generate impact. Several documents have analyzed the contribution of these approaches to the improvement of Management, Decision-Making, Identity Work, Governance, Hybrid Laws, Microfinance Institutions MFIs and Corporatizing.

Through this research the authors hope to contribute to the academic and professional community by summarizing the known literature and suggesting paths for further research precisely because it is necessary the cooperation.
\end{abstract}

Keywords: hybrid organization, hybrid impact, new public management, public-private partnerships, paradox

\section{Introduction}

Despite recent increased interest in hybrid organizations, literature about them remains sparse in many academic disciplines. Many of the numerous studies on hybridity defy easy classification (Cooney, 2006; Grossi \& Thomasson, 2015; Hasenfeld \& Gidron, 2005; Langton, 1987; L. Parker, 2011; Powell, 2003; Roundy, 2017; Stanton, 2004).

Hybridity, in the third sector, is not a new phenomenon. Since the 1980s, organizations have slowly started incorporating hybridity, causing minor disturbances, but only occasionally questioning their third root sector identity (Billis, 2010; Bryson \& Roering, 1987; Grimsey \& Lewis, 2002; Lan \& Hal, 1992; Perry \& Rainey, 1988; Stanton, 2004).

As Billis (2010) shows there exist this intermediate section contexts that we already know full well (Figure 1). At the intersection of public, profit and non-profit, the engine of innovation emerges. This time, when the concept of innovation is expressed, it refers to social innovation. In a historical period in which the crisis has played a dominant role in the negative effects suffered, it is necessary to identify the new starting points for regrowth and to intervene in what is called the Impact Economy (Calderini, Chiodo, \& Michelucci, 2018).

The role of these new organizations is fundamental for the generation of social impact and to share with the social economy (P. P. Biancone \& Radwan, 2019; Corvo \& Pastore, 2019; Pestoff, 2004). 
Until now, the lawmaker has always reasoned only by imagining that the actors were already existing actors with already existing tools, but instead within each was evolving something new, a new identity that in literature is defined: hybrid organization.

The growth of increasingly innovative and open models and tools makes it even more important to focus on the contribution that these organizations can make and for this reason the interest is to understand and put order in the literature to identify hybrid organizations even where they already existed but were not known as such and underestimated the effect (Alexius, Örnberg, \& Grossi, 2019; Bartocci, Grossi, \& Mauro, 2019).

Due to the recent proliferation of articles on this topic and their conflicting results, there is a need to summarize existing knowledge and to identify some implications and guidelines for further research.

There is a lot of literature that analyzes a small number of aspects of hybrid organizations, but, overall, there is a little systematic literature review. The authors or the study hope to fill this gap through their research questions.

This paper aims to provide a systematic review of the literature on hybrid organizations. More specifically, the study aims to answer the question of whether it is possible to analyze and map the evolution of hybrid organizations. If successful, the authors hope to identify the factors involved in the development of hybrid organizations. By conducting a systematic literature review into the evolution of hybridity, the authors hope to contribute to academic and professional communities by summarizing the known literature and suggesting avenues for further research. This paper is structured in the following way: the first section forms an introduction to the study, the second section names the research methodology used, the third section outlines the results of the analysis from the study, the fourth the discussion of the research and the fifth the conclusion of the study and basis for further research.

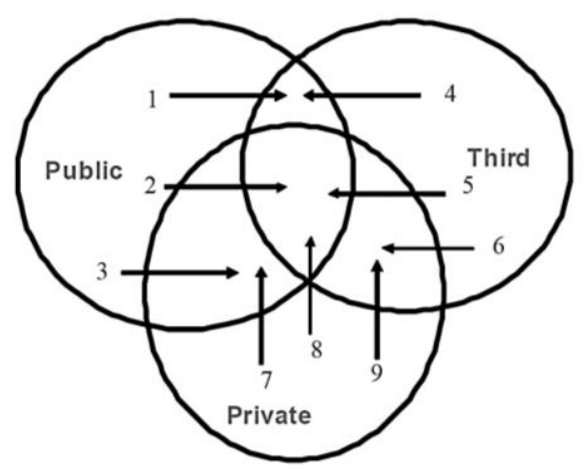

Figure 1. The three sectors and their hybrid zones

Source: (Billis, 2010)

\section{Research Methodology}

The document is based on a systematic review approach of Little et al. (2009), which aims to make the selection of literature and the review process transparent and replicable.

In order to answer the question of whether it is possible to analyse and map the evolution of hybrid organisations, the systematic review approach is the most effective. Only after the outcome of the research will it be possible to identify the factors involved in the development of hybrid organizations.

In order to make the research method robust and replicable, the authors have carried out the following steps: Scoping, Planning, Identification, Screening, Eligibility.

As already identified above, the researchers identified the demand for research and then carried out the entire Planning phase as Lipsey \& Wilson (2001) have defined by separating the demand and wondering what the criteria for exclusion and inclusion are that arise.

For accuracy, keywords to be used have been designated with an asterisk $(*)$ to show the range of possible studies, since many existing papers use slightly different keywords for the same concept, e.g. "hybrid" instead of "hybridity". Two classes of keywords have been selected:

1. Words related to the concept of hybridity at the theoretical and academic level are denoted as "hybrid*" and "theor", i.e. "T" keywords; and 
2. Words related to hybrid organizations on a more concrete or practical level in the territory are denoted "corporat*", "organization*", "public" and "private", i.e. "P" keywords. Our research incorporates a range of combinations of these two types of keywords.

A meta-search engine (TUTTO) was used in the research, which accessed the most well-known academic databases, such as Academic Law Reviews (LexisNexis), AGRIS (United Nations, Food and Agriculture Organization), American Chemical Society (CrossRef), arXiv, Cambridge Journals (Cambridge University Press), Informa - Taylor \& Francis (CrossRef), INFORMS Journals (168), JSTOR Archival Journals, JSTOR Current Journals, Lippincott Williams \& Wilkins Journals (Wolters Kluwer Health), MEDLINE/PubMed (NLM), Oxford Journals (Oxford University Press), Periodicals Archive Online, Periodicals Index Online, RSC Journals (Royal Society of Chemistry), Sage Journals (Sage Publications), Science Citation Index Expanded (Web of Science), ScienceDirect Journals (Elsevier), Scopus (Elsevier), Social Sciences Citation Index (Web of Science), Sociological Abstracts, SpringerLink, Taylor \& Francis Online - Journals, Thieme e-Journals (Thieme Publishing Group), University of Chicago Press Journals, Wiley (CrossRef) and Wiley Online Library.

In the Identification phase as demonstrated by Rosenthal (1979) and Cooper (2003) the problem of prejudice was eliminated to ensure the objectivity of the research and credibility in the results.

These results were then aggregated into a single list for comparative purposes. In this research only articles with a management focus were considered. Articles dealing specifically with technology were not included in our list. For the purposes of better research, only peer review journals were selected. To obtain a more general overview of the topic, no reference period was set; instead, articles accessed were those which were readily available, even if found to be irrelevant to the research, as is the case with papers from 1978. The same selection criteria were used to select the first language of the papers studied, thus European (namely Dutch, English, French, German, Italian, Lithuanian, Norwegian, Portuguese, Romanian, Russian and Spanish), Asian (namely Chinese, Malay, Japanese and Korean) and Middle Eastern languages (Arabic) were all included in this research analysis. After analysis, only English, French, Chinese Spanish and Portuguese stayed on topic.

Subsequently, the Screening phase was carried out, in which data were extrapolated and collected without any conflict of interest on the part of the authors, and finally, as defined by Greenland \& O'Rourke (2001), the Eligibility phase was managed, in which the themes of the quality of the study in meta-analysis were discussed and so, the initial selection (in October 2018) included over 1,000 papers. After deleting duplicated results, the total number of articles was reduced to 524. The authors of this paper read the abstract of each of these papers, focusing on the question: does this document analyze the concept of hybrid? Since hybridization is a relatively modern term, which of the older papers has relevant content were they to be defined today? Papers had to meet strict criteria in order to be considered.

Using this procedure, the number of documents selected for study was reduced to 98 . As decisions regarding inclusion and exclusion remain relatively subjective, this stage of the systematic review was conducted by all the authors. Best practice recommends that selection is performed by more than one reviewer (Mele e Belardinelli 2018; Tranfield, Denyer, e Smart 2003; Tummers et al. 2015).

At this stage, each article was read in full to see if it still met the criteria outlined. Only 42 papers remained. The following sections analyze these papers in details. In order to generate detailed analysis, the researchers deconstructed and reformed the content of each paper. This technique has seen to help combine and contrast the content of the papers (Denyer \& Tranfield, 2009; Mele \& Belardinelli, 2018).

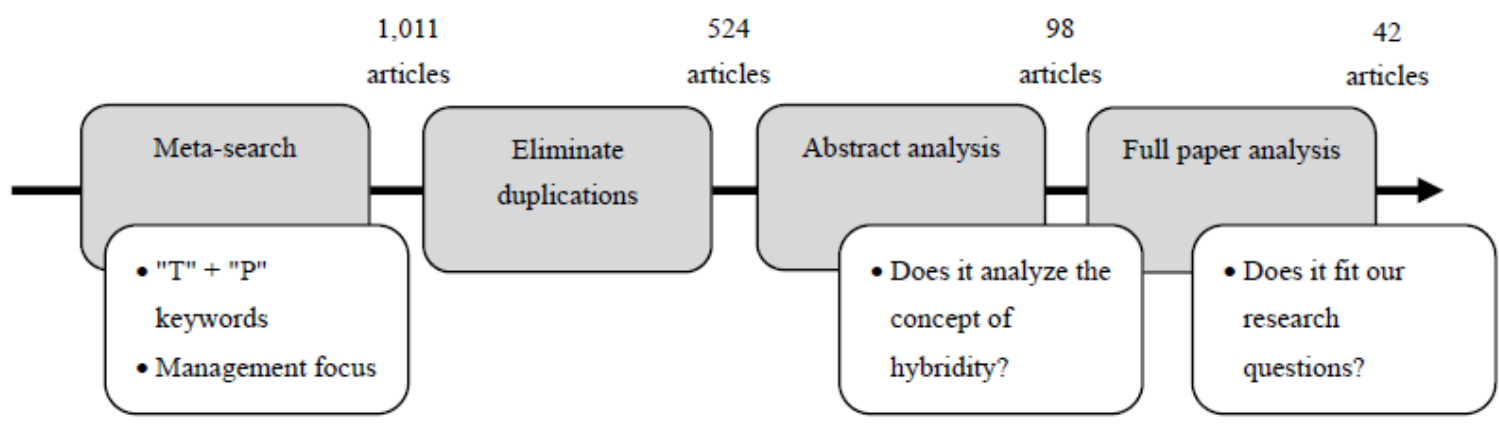

Figure 2. Screening methodology

Source: Our production 


\section{Analysis}

The authors of this paper reviewed the final 42 articles to identify commonalities in the process of hybridization as described by the full body of literature. Table I classifies the documents according to the topic on:

- The focus of research (New Public Management, paradox, joint-venture or Hybrid impact);

- The type of approach used (theoretical or practical);

- And the time of publication.

The knowledge distribution of Hybrid impact is homogeneous and highlights a growing interest in the subject and increasing relevance to New Public Management (henceforth, NPM), that is, half of the articles were focused on NPM.

Paradox-oriented practices and public-private joint-ventures are rarely studied, and when they are discussed, the majority uses a practical approach and supporting the case study.

Table 1. Methodologies and scope of the papers included in the review

\begin{tabular}{lccccccccccc}
\hline & $1998-2003$ & $2006-2008$ & $2009-2011$ & $2012-2014$ & $2015-2018$ \\
\hline FOCUS & $\mathrm{T}$ & $\mathrm{P}$ & $\mathrm{T}$ & $\mathrm{P}$ & $\mathrm{T}$ & $\mathrm{P}$ & $\mathrm{T}$ & $\mathrm{P}$ & $\mathrm{T}$ & $\mathrm{P}$ & TOTAL \\
Hybrid impact & 1 & 2 & 2 & 2 & 1 & 1 & 1 & 1 & 2 & 3 & $\mathbf{1 6}$ \\
NPM & 0 & 2 & 1 & 1 & 0 & 5 & 2 & 5 & 0 & 5 & $\mathbf{2 1}$ \\
Paradox & 0 & 0 & 0 & 0 & 0 & 0 & 1 & 0 & 0 & 3 & $\mathbf{4}$ \\
Public-private partnerships & 0 & 0 & 0 & 0 & 0 & 0 & 0 & 1 & 0 & 0 & $\mathbf{1}$ \\
TOTAL & $\mathbf{1}$ & $\mathbf{4}$ & $\mathbf{3}$ & $\mathbf{3}$ & $\mathbf{1}$ & $\mathbf{6}$ & $\mathbf{4}$ & $\mathbf{7}$ & $\mathbf{2}$ & $\mathbf{1 1}$ & $\mathbf{4 2}$ \\
\hline
\end{tabular}

Source: Our production

Table 2. Papers that analyse hybridity (for explanation of the abbreviations, see the note at the bottom of Table 2)

\begin{tabular}{|c|c|c|c|c|c|}
\hline $\mathbf{N}$ & PAPER & FOCUS & METHOD & PRACTICE & CONTENT \\
\hline & (Deem, 1998) & NPM & $\mathrm{CS}$ & Management & $\begin{array}{l}\text { Applicability of recent theories positing the existence } \\
\text { of new approaches to the management of public } \\
\text { sector institutions, to current organisational forms } \\
\text { and management strategies in universities in the } \\
\text { United Kingdom. }\end{array}$ \\
\hline & (Goldoff, 2000) & $\mathrm{HI}$ & $E$ & Decision-Making & $\begin{array}{l}\text { Interconnection and potential "new paradigm" } \\
\text { between the three areas of decision making: risk } \\
\text { assessment, chaos theory and strategic management } \\
\text { and the non-profit sector, public or private. }\end{array}$ \\
\hline & $\begin{array}{l}\text { (Greve \& Andersen, } \\
\text { 2001) }\end{array}$ & $\mathrm{HI}$ & $\mathrm{CS}$ & Privatization & $\begin{array}{l}\text { Examine when Tele Danmark was fully privatized } \\
\text { and the effect of two theoretical perspectives are } \\
\text { introduced: rational-technical and cultural. }\end{array}$ \\
\hline & $\begin{array}{l}\text { (Klijn \& Teisman, } \\
2003)\end{array}$ & HI & $\mathrm{CS}$ & PPPs & $\begin{array}{l}\text { Through analyses of three PPPs in the Netherlands it } \\
\text { emerged that partners tend to return to traditional } \\
\text { forms, subcontracting and separating responsibilities } \\
\text { as they have difficulties in making decisions. }\end{array}$ \\
\hline 5 & (Kickert, 2003) & NPM & $\mathrm{CS}$ & $\begin{array}{l}\text { Public } \\
\text { Management }\end{array}$ & $\begin{array}{l}\text { The research shows the impacts of NPM laws as } \\
\text { companies have gone beyond mandatory legislation } \\
\text { to improve practice. }\end{array}$ \\
\hline 6 & $\begin{array}{l}\text { (Meyer } \quad \& \\
\text { Hammerschmid, } \\
\text { 2006) }\end{array}$ & $\mathrm{HI}$ & $\mathrm{CS}$ & Identity Work & $\begin{array}{l}\text { The effect of new managerial logic in the Austrian } \\
\text { public sector in place of an "old" administrative } \\
\text { orientation }\end{array}$ \\
\hline 7 & $\begin{array}{l}\text { (Barry, Berg } \quad \& \\
\text { Chandler, 2006b) }\end{array}$ & $\mathrm{HI}$ & LR & Management & $\begin{array}{l}\text { Re-conceptualising public sector managerial change } \\
\text { based on the theory of social movement, an approach } \\
\text { that fits in with political sociology. }\end{array}$ \\
\hline & $\begin{array}{ll}\text { (Barry, Berg } & \text { \& } \\
\text { Chandler, 2006a) } & \end{array}$ & NPM & LR & Identity Work & $\begin{array}{l}\text { Following a change in higher education with the } \\
\text { advent of NPM, the effect of gender and managerial } \\
\text { identity in organisational life in the Swedish and } \\
\text { English context is analysed. }\end{array}$ \\
\hline & (Chan \& Chow, 2007) & NPM & $\mathrm{CS}$ & Management & $\begin{array}{l}\text { Through research is demonstrated the effect of } \\
\text { Chinese culture and office work have transformed } \\
\text { various Western approaches, including NPM and } \\
\text { management control on patterns of managerial and } \\
\text { organizational behavior. }\end{array}$ \\
\hline & (Collings, Gunnigle \& & $\mathrm{HI}$ & $\mathrm{CS}$ & Change & Emergence of the hybrid IR management system and \\
\hline
\end{tabular}




\begin{tabular}{|c|c|c|c|c|c|}
\hline $\mathbf{N}$ & PAPER & FOCUS & METHOD & PRACTICE & CONTENT \\
\hline & Morley, 2008) & & & & $\begin{array}{l}\text { the creation of new, more reflective traditions of the } \\
\text { US business system. }\end{array}$ \\
\hline & (Rehn, 2008) & $\mathrm{HI}$ & $\mathrm{E}$ & Management & $\begin{array}{l}\text { Mapping concepts in hybrid management and } \\
\text { subsequent conceptual evolution of the need to study } \\
\text { popular culture in organizational studies. }\end{array}$ \\
\hline & $\begin{array}{l}\text { (Melián-González \& } \\
\text { Bulchand-Gidumal, } \\
\text { 2009) }\end{array}$ & NPM & CS & Governance & $\begin{array}{l}\text { The impact of NPM is based on principles such as } \\
\text { specialization and desegregation of public } \\
\text { organizations, and on practices such as outsourcing } \\
\text { and internal market development. }\end{array}$ \\
\hline 13 & (Green, 2009) & NPM & $\mathrm{CS}$ & Governance & $\begin{array}{l}\text { The principles of the NPM gave rise to the } \\
\text { government of New Labour in the UK and it was } \\
\text { demonstrated that an illusory screen of plural, } \\
\text { autonomous and enhanced distribution networks for } \\
\text { sport obscured the regulation from the centre. }\end{array}$ \\
\hline & $\begin{array}{ll}\text { (Lockwood } & \& \\
\text { Davidson, 2010) } & \end{array}$ & $\mathrm{HI}$ & $\mathrm{CS}$ & Governance & $\begin{array}{l}\text { Hybridity in the management of natural resources } \\
\text { both inside and outside Australian neoliberalism. }\end{array}$ \\
\hline & $\begin{array}{l}\text { (Harhoff } \\
\text { Mayrhofer, 2010) }\end{array}$ & $\mathrm{HI}$ & $\mathrm{E}$ & Management & $\begin{array}{l}\text { This paper outlined the concept of managing user } \\
\text { communities and hybrid innovation and gave as an } \\
\text { example the reputation of a group affected by } \\
\text { stakeholders and the perception of the service } \\
\text { rendered. }\end{array}$ \\
\hline 16 & (Foljanty-Jost, 2011) & NPM & $\mathrm{CS}$ & $\begin{array}{l}\text { Public } \\
\text { Management }\end{array}$ & $\begin{array}{l}\text { The legislative impact of NPM in Germany and } \\
\text { Japan. First, more favourable preconditions for the } \\
\text { positive impact on local democracy, while in Japan, } \\
\text { with a relatively weak tradition of local } \\
\text { self-government and resources, the focus is on } \\
\text { co-producing services with local governments, while } \\
\text { at the same time offering more opportunities. }\end{array}$ \\
\hline & $\begin{array}{l}\text { (Flinders, 2011, pp. } \\
\text { 1998-2009) }\end{array}$ & NPM & $\mathrm{CS}$ & Governance & $\begin{array}{l}\text { Derived theories in relation to multi-level } \\
\text { governance in order to frame delegated governance. } \\
\text { Revelation of a complex model of resource } \\
\text { dependence, motivation and incentives. }\end{array}$ \\
\hline 18 & (Bezes et al., 2011) & NPM & $\mathrm{CS}$ & Identity Work & $\begin{array}{l}\text { Empirical analysis between NPM and some } \\
\text { professional groups to monitor when the former may } \\
\text { influence the decline of the latter. }\end{array}$ \\
\hline 19 & (Abdul-Aziz, 2012) & $\mathrm{HI}$ & $\mathrm{CS}$ & PPPs & $\begin{array}{l}\text { The control mechanisms used by Malaysian public } \\
\text { bodies are associated with archetypes of bureaucracy } \\
\text { and hybrid governance with final proposals for } \\
\text { organisational change. }\end{array}$ \\
\hline & $\begin{array}{l}\text { (Saz-Carranza } \\
\text { Longo, 2012) }\end{array}$ & PPPs & $\mathrm{S}$ & Governance & $\begin{array}{l}\text { Cross-sectoral inter-organisational partnerships, } \\
\text { alliances and networks have become extremely } \\
\text { popular making their management central to the } \\
\text { success of the alliance. }\end{array}$ \\
\hline 21 & (Kinder, 2012) & NPM & CS & $\begin{array}{l}\text { Public } \\
\text { Management }\end{array}$ & $\begin{array}{l}\text { Highlighting a theoretical framework for innovation } \\
\text { in local public services, using listening and learning, } \\
\text { illustrating its usefulness in a case study. }\end{array}$ \\
\hline & $\begin{array}{l}\text { (Rayner, Lawton \& } \\
\text { Williams, 2012) }\end{array}$ & NPM & $\mathrm{CS}$ & Organization & $\begin{array}{l}\text { The negative impact of externally imposed reforms } \\
\text { using tools such as financial incentives and } \\
\text { performance targets on public service ethics has been } \\
\text { demonstrated and tested. }\end{array}$ \\
\hline 23 & (MacCarthaigh, 2012) & NPM & $\mathrm{CS}$ & Organization & $\begin{array}{l}\text { Suggestion of avenues for future investigations } \\
\text { following the identification of distinctive } \\
\text { institutional features and dominant trends in Irish } \\
\text { political-administrative governance with a focus on } \\
\text { the NPM. }\end{array}$ \\
\hline 24 & (Ratner, 2012) & $\mathrm{P}$ & $\mathrm{E}$ & Identity Work & $\begin{array}{l}\text { Apprehension of uncertainty and related group } \\
\text { conflicts influence the interaction between public } \\
\text { sector change and employee identity. }\end{array}$ \\
\hline 25 & $\begin{array}{l}\text { (Garrone, Grilli \& } \quad \& \\
\text { Rousseau, 2013) }\end{array}$ & $\mathrm{HI}$ & $\mathrm{E}$ & $\begin{array}{l}\text { Public } \\
\text { Management }\end{array}$ & $\begin{array}{l}\text { Management discretion is a significant source of } \\
\text { inefficiency in municipal enterprises demonstrated } \\
\text { through concentration on local government } \\
\text { restructuring measures: partial privatisation, } \\
\text { inter-municipal joint ventures and the presence of } \\
\text { external directors. }\end{array}$ \\
\hline 26 & $\begin{array}{lr}\text { Nieto } & \text { Morales, } \\
\text { Wittek, \& } & \text { Heyse, } \\
\end{array}$ & NPM & CS & Organization & $\begin{array}{l}\text { Public organisations are more like private } \\
\text { organisations, but with obvious differences is the }\end{array}$ \\
\hline
\end{tabular}




\begin{tabular}{|c|c|c|c|c|c|}
\hline $\mathbf{N}$ & PAPER & FOCUS & METHOD & PRACTICE & CONTENT \\
\hline & 2013) & & & & $\begin{array}{l}\text { demonstration of a research on } 61 \text { public } \\
\text { organisations and } 61 \text { private organisations in } \\
\text { Netherlands. }\end{array}$ \\
\hline & (Casini, 2014) & NPM & $\mathrm{E}$ & Hybrid Laws & $\begin{array}{l}\text { The distinction between international and national } \\
\text { law, public and private law with the aim of the ways } \\
\text { in which hybrid global institutions exercise their } \\
\text { powers has led to the emergence of multipolar } \\
\text { administrative law. }\end{array}$ \\
\hline & (Norman, 2014) & NPM & CS & Governance & $\begin{array}{l}\text { Internal transformation like a new reform of } \\
\text { Cambodian public management and consequent } \\
\text { study of the evolution of the new governance } \\
\text { framework and civil society organisations. }\end{array}$ \\
\hline 29 & (Durant, 2014) & NPM & CS & Hybrid Laws & $\begin{array}{l}\text { The administrative order dominated by the public } \\
\text { sector because of its focus on bureaucratic rather than } \\
\text { democratic administration is the legacy of federal } \\
\text { administrative reform. }\end{array}$ \\
\hline 30 & (Bird, 2015) & NPM & CS & $\begin{array}{l}\text { Public } \\
\text { Management }\end{array}$ & $\begin{array}{l}\text { Privatizzazione delle aziende e a cambiamenti } \\
\text { modernizzati nella governance e nelle condizioni } \\
\text { organizzative sono stati frutto dell'impatto della } \\
\text { NPM. }\end{array}$ \\
\hline 31 & (Simonet, 2015) & NPM & CS & Management & $\begin{array}{l}\text { The re-centralisation of public agencies is the } \\
\text { objective of the NPM verified in areas such as citizen } \\
\text { participation and professional satisfaction of doctors. } \\
\text { In addition, however, subsequent health reforms } \\
\text { indicate a convergence towards a hybrid system. }\end{array}$ \\
\hline & $\begin{array}{l}\text { (Kleynjans \& Hudon, } \\
\text { 2016) }\end{array}$ & $\mathrm{HI}$ & CS & MFIS & $\begin{array}{l}\text { This is a comparative study of the codes of a } \\
\text { Mexican network of hybrid organizations including } \\
\text { seven MFIs. The emphasis is placed on "socially } \\
\text { oriented" principles and on terms such as "people" } \\
\text { and "common good". }\end{array}$ \\
\hline 33 & (Aagaard, 2016) & $\mathrm{HI}$ & CS & $\begin{array}{l}\text { Public } \\
\text { Management }\end{array}$ & $\begin{array}{l}\text { Post-transformative leaders are invited to move from } \\
\text { collaborative strategies to strategies of manipulation, } \\
\text { hypocrisy and diversion of institutional logic by } \\
\text { demonstrating that public managers can influence the } \\
\text { mix of institutional logic in a process of } \\
\text { organizational change. }\end{array}$ \\
\hline 34 & $\begin{array}{l}\text { (Kirkpatrick, } \\
\text { Kuhlmann, Hartley, } \\
\text { Dent \& Lega, 2016) }\end{array}$ & $\mathrm{HI}$ & $\mathrm{CS}$ & Management & $\begin{array}{l}\text { Strong impact on the leadership structure of time } \\
\text { management (hybrid) or roles, through a push to } \\
\text { collaboration of full-time or part-time professionals } \\
\text { in service management. }\end{array}$ \\
\hline & $\begin{array}{l}\text { (Lindlbauer, Winter, \& } \\
\text { Schreyögg, 2016) }\end{array}$ & NPM & CS & Corporatizing & $\begin{array}{l}\text { Privatisation of companies can be an effective } \\
\text { alternative, a discovery that has led to a number of } \\
\text { implications for practice and research. }\end{array}$ \\
\hline & $\begin{array}{l}\text { (Skelcher \& Smith, } \\
\text { 2017) }\end{array}$ & $\mathrm{HI}$ & CS & Performance & $\begin{array}{l}\text { Through a process of hybridization, public and } \\
\text { non-profit organizations can contain apparently } \\
\text { irreconcilable institutional logics, such as public } \\
\text { service and market survival. }\end{array}$ \\
\hline & $\begin{array}{l}\text { (Bode, Lange, } \quad \& \\
\text { Märker, 2017) }\end{array}$ & NPM & CS & $\begin{array}{l}\text { Impact of Hybrid } \\
\text { Laws }\end{array}$ & $\begin{array}{l}\text { The social mission that could potentially become } \\
\text { more like that of companies with a view to improving } \\
\text { public management. }\end{array}$ \\
\hline & $\begin{array}{l}\text { (Kirkpatrick, Altanlar, } \\
\& \text { Veronesi, 2017) }\end{array}$ & NPM & CS & Corporatizing & $\begin{array}{l}\text { Corporatization co-occurs with change and increases } \\
\text { the possibility that corporatization leads to both more } \\
\text { managed and uncontrolled organizations } \\
\text { simultaneously. }\end{array}$ \\
\hline & $\begin{array}{l}\text { (Torchia \& Calabrò, } \\
\text { 2018) }\end{array}$ & $\mathrm{HI}$ & CS & PPPs & $\begin{array}{l}\text { Through the case study it has been demonstrated that } \\
\text { despite its great success, the PPP analysed has some } \\
\text { governance problems that need to be addressed. }\end{array}$ \\
\hline & $\begin{array}{l}\text { (Carollo \& Guerci, } \\
\text { 2018) }\end{array}$ & $\mathrm{P}$ & S & Identity Work & $\begin{array}{l}\text { Analysis of the relationship between paradoxes and } \\
\text { work on identity, identifying three main tensions that } \\
\text { influence their construction process. }\end{array}$ \\
\hline & $\begin{array}{l}\text { (Hahn, Figge, Pinkse, } \\
\& \text { Preuss, 2018) }\end{array}$ & $\mathrm{P}$ & $\mathrm{E}$ & $\begin{array}{l}\text { Corporate } \\
\text { Sustainability }\end{array}$ & $\begin{array}{l}\text { Definition of the descriptive, instrumental and } \\
\text { normative aspects that lead to a definition of the } \\
\text { paradoxical perspective on corporate sustainability. }\end{array}$ \\
\hline & $\begin{array}{l}\text { (Kannothra, Manning, } \\
\text { \& Haigh, 2018) }\end{array}$ & $\mathrm{P}$ & LR & Organization & $\begin{array}{l}\text { The focus on impact sourcing demonstrates the } \\
\text { growing interest in the way hybrid organizations } \\
\text { manage paradoxical social and business tensions. }\end{array}$ \\
\hline
\end{tabular}




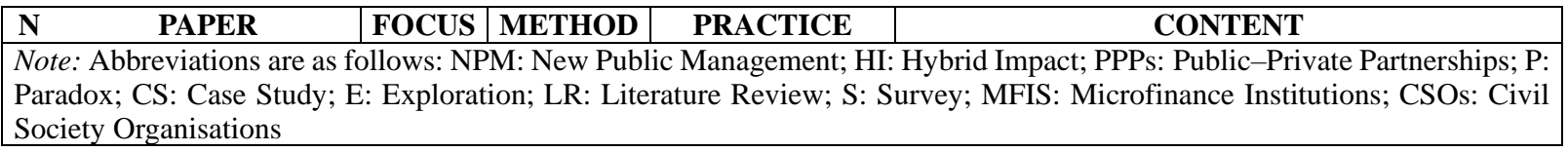

Source: Our production

Table 3. Mapping of the authors and their practice

\begin{tabular}{|c|c|c|c|c|}
\hline PRACTICE & HI & $\mathbf{P}$ & NPM & PPPs \\
\hline Change & (Collings et al., 2008) & & & \\
\hline $\begin{array}{l}\text { Corporate } \\
\text { Sustainability } \\
\end{array}$ & & $\begin{array}{lll}\text { (Hahn } & \text { et } & \text { al., } \\
2018) & & \\
\end{array}$ & & \\
\hline Corporatizing & & & $\begin{array}{l}\text { (Lindlbauer et al., 2016) } \\
\text { (Kirkpatrick et al., 2017) }\end{array}$ & \\
\hline Decision-Making & (Goldoff, 2000) & & & \\
\hline Governance & $\begin{array}{l}\text { (Lockwood \& Davidson, } \\
\text { 2010) }\end{array}$ & & $\begin{array}{l}\text { (Melián-González \& } \\
\text { Bulchand-Gidumal, 2009) } \\
\text { (Green, 2009) } \\
\text { (Flinders, 2011) } \\
\text { (Norman, 2014) }\end{array}$ & $\begin{array}{l}\text { (Saz-Carranza \& } \\
\text { Longo, 2012) }\end{array}$ \\
\hline Hybrid Laws & & & $\begin{array}{l}\text { (Casini, 2014) } \\
\text { (Durant, 2014) }\end{array}$ & \\
\hline Identity Work & $\begin{array}{l}\text { (Meyer \& Hammerschmid, } \\
\text { 2006) }\end{array}$ & $\begin{array}{ll}\text { (Ratner, 2012) } \\
\text { (Carollo } \\
\text { Guerci, 2018) }\end{array}$ & $\begin{array}{l}\text { (Barry et al., 2006b) } \\
\text { (Bezes et al., 2011) }\end{array}$ & \\
\hline $\begin{array}{l}\text { Impact Of Hybrid } \\
\text { Laws }\end{array}$ & & & (Bode et al., 2017) & \\
\hline Management & $\begin{array}{l}\text { (Barry et al., 2006a) } \\
\text { (Rehn, 2008) } \\
\text { (Harhoff \& Mayrhofer, 2010) } \\
\text { (Kirkpatrick et al., 2016) }\end{array}$ & & $\begin{array}{l}\text { (Deem, 1998) } \\
\text { (Chan \& Chow, 2007) } \\
\text { (Simonet, 2015) }\end{array}$ & \\
\hline $\begin{array}{l}\text { Microfinance } \\
\text { Institutions (Mfis) }\end{array}$ & (Kleynjans \& Hudon, 2016) & & & \\
\hline Organization & & $\begin{array}{l}\text { (Kannothra et al., } \\
\text { 2018) }\end{array}$ & $\begin{array}{l}\text { (Rayner et al., 2012) } \\
\text { (Maccarthaigh, 2012) } \\
\text { (Nieto Morales et al., } \\
\text { 2013) }\end{array}$ & \\
\hline Performance & (Skelcher \& Smith, 2017) & & & \\
\hline Privatization & (Greve \& Andersen, 2001) & & & \\
\hline $\begin{array}{l}\text { Public } \\
\text { Management }\end{array}$ & $\begin{array}{l}\text { (Garrone et al., 2013) } \\
(\text { Aagaard, 2016) }\end{array}$ & & $\begin{array}{l}\text { (Kickert, 2003) } \\
\text { (Foljanty-Jost, 2011) } \\
\text { (Kinder, 2012) } \\
\text { (Bird, 2015) }\end{array}$ & \\
\hline $\begin{array}{l}\text { Public-Private } \\
\text { Partnerships }\end{array}$ & $\begin{array}{l}\text { (Klijn \& Teisman, 2003) } \\
\text { (Abdul-Aziz, 2012) } \\
\text { (Torchia \& Calabrò, 2018) }\end{array}$ & & & \\
\hline
\end{tabular}

Source: Our production

Table 2 provides a summary of the literature. The documents were classified into three categories with the following focuses:

1. The phenomenon analyzed;

2. The methodology adopted; and

3. The sector in which the phenomenon occurs.

To simplify the results found in Table 3, it is possible to view the focus in which the researchers have investigated.

In category 1, 21 papers considered only practices related to NPM from different points of view, analyzing the causes, effects and state of development. These paper are (Barry et al., 2006b; Bezes et al., 2011; Bird, 2015; Bode et al., 2017; Casini, 2014; Chan \& Chow, 2007; Deem, 1998; Durant, 2014; Flinders, 2011; Foljanty-Jost, 2011; Green, 2009; Kickert, 2003; Kinder, 2012; Kirkpatrick et al., 2017; Lindlbauer et al., 2016; Maccarthaigh, 2012; Melián-González \& Bulchand-Gidumal, 2009; Nieto Morales et al., 2013; Norman, 2014; Rayner et al., 


\section{2; Simonet, 2015).}

In category 2, four papers considered the concept of Paradox (henceforth, P) recognizing the phenomenon of multiple conflicts that characterize sustainability in business organizations. These papers are (Carollo \& Guerci, 2018; Hahn et al., 2018; Kannothra et al., 2018; Ratner, 2012).

In category 3, one paper (Saz-Carranza \& Longo, 2012), considered public-private partnerships (henceforth, PPPs). This is an area of research that requires more study but provides an important insight into the synergy between private and public with a potentially significant impact.

In category 4, 16 papers considered Hybrid Impact (henceforth, HI). They had a limited scope and only considered the evaluation and impact of hybridization on social and environmental performance. These papers are (Aagaard, 2016; Abdul-Aziz, 2012; Barry et al., 2006b; Collings et al., 2008; Garrone et al., 2013; Goldoff, 2000; Greve \& Andersen, 2001; Harhoff \& Mayrhofer, 2010; Kirkpatrick et al., 2016; Kleynjans \& Hudon, 2016; Klijn \& Teisman, 2003; Lockwood \& Davidson, 2010; Meyer \& Hammerschmid, 2006; Rehn, 2008; Skelcher \& Smith, 2017; Torchia \& Calabrò, 2018). Note that there are no papers that included a mixed focus.

Table 3 shows, also, in which functional areas hybridization occurred and which authors posed a research question deliberately designed to make their own contribution to the existing body of original research. The practices examined are: Change, Corporate Sustainability, Corporatization, Decision-Making, Governance, Hybrid Laws, Identity Work, Impact of Hybrid Laws, Management, Microfinance Institutions (henceforth, MFIs), Organization, Performance, Privatization, Public Management and PPPs.

\section{$3.1 N P M$}

Deem (1998) says that 'New managerialism' represents a way of understanding and categorizing attempts to impose managerial techniques.

This identity is usually associated at medium and large enterprises for profit, public sector and voluntary organisations (Clarke \& Newman, 1997; Itzin \& Newman, 1995; McLaughlin, 1994; Reed \& Anthony, 1993).

Clarke and Newman (1997) show that the concept of "new managerialism" can be detected within organizational models, cultures and management technologies of organizations.

The change that this new concept brought about was the grafting of what is defined as Corporatizing as highlighted by Lindlbauer et al. (2016), Kirkpatrick et al. (2017). The transaction takes place in the concept of governance Melián-González and Bulchand-Gidumal (2009), Green (2009), Flinders (2011), Norman (2014) and consequently in the Identity Work, because the figure of the manager changes, the management of employees changes with the aim of maximizing results and performance as demonstrated by Barry et al. (2006a) and Bezes et al. (2011).

The research shows, as Rayner et al. (2012), Maccarthaigh (2012), Nieto Morales et al. (2013) studied, the NPM has had an impact on the concept of Organization also changing the approach of Management, what emerges from the studies of Deem (1998), Chan and Chow (2007) and Simonet (2015), discovering that administrative systems can improve performance by importing innovations in public management.

When a change of this kind occurs, the subjects involved do not all react in the same way, for this reason it distinguish best practices and therefore should be transferable but it is not always possible because of the characteristics of the country or type of administrative system (Kliksberg, 2005; König, 2003; Manning, 2001).

In this process of change that the NPM has brought about, Public Management has undergone an important innovation in that it has had to adapt and act through reforms, as studied by Kickert (2003) and Foljanty-Jost (2011). The propensity to performance, as analyzed by Kinder (2012), is a different vision for the public administration that, however, makes it enter the process of hybridization that the ecosystem needs to progress.

The NPM has also had an impact on the legislative area. Casini (2014) and Durant (2014) make an excellent judicial analysis on the phenomenon of hybridization. Their research refers to the existence of two major dualisms within contemporary legal systems which lead to a distinction between international law and national law and the second between public law and private law. For example the public / private gap can be traced back to the origins of administrative law, which materialized as a type of "special" law, distinct from the oldest private law (Casini, 2014; Cassese, 2012; Sand, 2013)

Also Bode et al. (2017) highlighted the Impact of Hybrid Laws and the organizational management that involves this phenomenon. These scholars make it clear that thinking of simple distinctions can lead to a lack of understanding of the real complexity they now have as they are profoundly transformed (Aman, 2008; Mac Amhlaigh, Michelon, \& Walker, 2013; Schmitt, 2014). 


\subsection{Paradox}

Marquis and Battilana (2009) define what is the central paradox for hybrid organizations: the simultaneous pursuit of social missions and financial objectives. Making it clear that the tensions intensify when hybrids operate globally and simultaneously catering to international clients and local communities.

Carollo and Guerci's studies (2018) underline that the paradox theory relies on complexity thinking, and it does not lend itself to positivist research approaches. Additionally, the basic unit of a paradox is its underlying tension, which consists of elements that seem logical individually but inconsistent and even absurd when juxtaposed.

Lewis (2000) explained that a paradox perspective intervenes on the tension when, despite its inconsistency, it is conceived as contradictory yet interrelated elements that exist simultaneously and persist over time. From the perspective of paradox theory, good strategies encourage actors to live with paradoxes, and accept them as persistent and unsolvable puzzles (Clegg, da Cunha, \& e Cunha, 2002; Lewis, 2000; Poole \& Van de Ven, 1989; W. K. Smith \& Lewis, 2011; Van der Byl \& Slawinski, 2015).

It is connected to the concept of identity analyzed by Meyer e Hammerschmid (2006), Ratner (2012) and Carollo and Guerci (2018) that of the paradox. It refers to people who are engaged in forming, repairing, maintaining, strengthening or revising constructions that are productive of a sense of coherence and distinction of the self. Brown (2015) defines Identity work the most significant metaphor for the analysis of identity building in and around organizations (Schultz, Schreyoegg, \& Von Reitzenstein, 2013). Many researchers tend to highlight the tensions and struggles that characterize the individual processes of identity creation, although work on identity is aimed at producing a positive and distinct sense of self (Alvesson, 2010; Beech, Gilmore, Hibbert, \& Ybema, 2016; Brown, 2015; Gotsi, Andriopoulos, Lewis, \& Ingram, 2010; Lähdesmäki, 2012; Phillips, 2013; Sveningsson \& Alvesson, 2003; Watson, 2008).

In the concept of paradox of the identity of workers, and managers, that move from private companies to public ones, they embody enterprise through their 'personal brand' in the labor market and an anti-bureaucratic, pro-change orientation. However Street and Gallupe (2009), explain that these characteristics, and the perishability of their status, limit the ability of these actors to embed enterprise. Additionally Ratner (2012), it is through the loss of their novel enterprising appearance of going native that change is reinforced. Thus, paradoxically, their enterprising nature runs counter to the adoption of techniques of the enterprise.

These studies have implications in understanding the idea of enterprise as organizational change, just like the promotion of management ideas more generally. Despite the fact that hybridization involves a mix of visions between profit, non-profit and therefore social innovation, a paradoxical perspective does not emphasize business considerations on concerns for environmental protection and social welfare at the social level (D. J. Cooper \& Robson, 2006; Hahn et al., 2018; Street \& Gallupe, 2009; Sturdy \& Wright, 2008).

\subsection{Public-Private Partnerships}

Without being explicit, the concept of hybrid is analyzed by researchers who study joint ventures between public and private partnerships. Using the applied research method previously identified, it is possible to widen the concept of hybridity to a more deep-seated resonance.

Cross-sector inter-organizational partnerships, alliances and networks have become extremely popular. Societal-level institutional logics have an important role in cross-sector alliances, making their management central to alliance success (Agranoff, 2007; Dyer, Powell, Sakakibara, \& Wang, 2007; Rittel \& Webber, 1973). As such, they are vital in managing a problem in a group. Accordingly, inter-organizational and cross-sector cooperation is needed to attain the meta-objective of economic development, leading theightened importance in the performance (Huuskonen \& Kourula, 2012; Huxham \& Beech, 2003; Klijn \& Teisman, 2003; Saz-Carranza \& Longo, 2012).

Generally, this concept is defined as PPPs. This is so because the term PPP is commonly understood to refer to private participation - usually providing the design, finance and operation - in public infrastructure development. In a PPP, the public sector has a specific idea of what service or product it wants, or at a minimum, what the public need is in searching for a solution (Herranz Jr, 2007; Wall \& Connolly, 2009).

PPPs, loosely defined as cooperative institutional arrangements between public and private sector actors, have gained wide interest around the world. However, there is little agreement on the idea of a PPP. Some see it as a new governance tool that will replace the traditional method of contracting for public services through competitive tendering. Others see PPPs as a new expression in the language of public management, one intended to include older, established procedures of involvement of private organizations in the delivery of public services. Yet others view PPPs as a new way to handle infrastructure projects, such as building tunnels and renewing 
harbours (Hart, 2003; Hodge \& Greve, 2007; Linder, 1999; Savas, 2000).

Hodge and Greve (2007) explain that PPPs are related to infrastructure projects and therefore are institutional cooperation agreements that create new organisational units. In the context of infrastructure projects, PPPs are also seen as financial models that allow the public sector to use private financial capital in a way that increases the possibilities of both the elected administration and the private enterprise. Most partnerships stress the need to create PPPs, as they can benefit both the public and private sectors. The reasoning is simple - both the public and private sectors have specific qualities, and if these qualities are combined, the result will be better for all (Klijn \& Teisman, 2003; Teisman \& Klijn, 2002; Williamson, 1985).

New products or services are the result that cooperation may entail because they would not have been born if public and private organisations had not shared them (Klijn \& Teisman, 2003; Roehrich, Lewis, \& George, 2014; Williamson, 1985; Wong et al., 2015).

Linder (1999) through his study explains that there is a broader alternative view of PPPs as a game designed to "cloud" other strategies and goals. One of these aims is the privatisation and encouragement of private providers to provide public services at the expense of public organisations themselves.

The finding is important among ideological blind spots that appear among many PPP defenders, such as the central treasury departments, who seem more intent on defending politics than on administrative matters. Certainly, a better definition of the concept and consequently aligning the organization can lead to good governance, which is both effective and responsible (Hodge, 2004; Hodge \& Greve, 2007; Hodge, Greve, \& Boardman, 2010),

\subsection{Hybrid Impact}

The fourth concept that results from the analysis is that the hybrid phenomenon is analyzed from the point of view of the impact generated in decision-making, privatization, public-private partnerships, identity work, management, governance and performance.

The change as highlighted by Collings et al. (2008) is the influential factor in the transition to the concept of hybrid. The change takes place in the concept of Decision-Making as Goldoff (2000) has studied, of governance (Lockwood \& Davidson, 2010) and consequently in the Identity Work, because the figure of the manager is changed, the management of employees is changed with the aim of maximizing results and performance as Skelcher and Smith showed (2017).

The research demonstrates, as Greve and Andersen (2001) states, that the transition to privatization is one of the grafts that have led to change and the definition of hybrid organizations also changing the approach of Management, that is what emerges from the studies of Barry et al. (2006a), Rehn (2008), Harhoff and Mayrhofer (2010), Kirkpatrick et al. (2016). The consequent activities that emerge are the commercialization of public sector services and the need to monitor efficiency and effectiveness through the measurement of results and performance (Hodge \& Greve, 2007; Skelcher \& Smith, 2017). In this overview of hybrid changes has certainly changed the Public Management, in fact Garrone et al. (2013) and Aagaard (2016) study the phenomenon of the change in the organizational culture of the public sector to look more like the private sector "for profit".

The organization is as crucial as technology in understanding the information revolution; this revolution gives rise to network forms of organization. The rise of networks will continue to accrue power to non-state actors, more than to states, until states adapt by learning to mould hierarchies into hybrids that incorporate elements of network design (Arquilla \& Ronfeldt, 1997).

In a hybrid regime of practices, multiple mentalities of rule and multiple logics are simultaneously evident. Hybridization can potentially occur between one or more of:

I. A dominant form, such as neoliberalism;

II. Vestiges of once dominant now superseded mentalities, such as welfarism;

III. Waxing and waning but nonetheless durable alternatives; and

IV. Newly emergent modes that arise as a response to novel or newly recognised problems.

Hybridized structures may be evident within a regime of practices when the authors of a governance programme actively include components from multiple logics, so that the programme itself is a 'meta-governance' hybrid (Lockwood \& Davidson, 2010).

Additionally, any study of management and organization is always already a study of popular culture, and that the concept of a 'cultural studies of organization' might be something of a tautology. Two, that the (at least partly 
unconscious) separation of the subjects is into 'highbrow' and 'lowbrow' study - something that the field of cultural studies tried to overcome yet is still well used in organization studies. Three, that in order to escape such simplified separations, it might be productive to place a particular emphasis on the study of phenomena in popular culture as hybrid forms rather than cultural 're-presentations', that is, forms where distinctions between management discourse and popular culture discourse are challenged or disappear completely (Curran, Bauer, Mittman, Pyne, \& Stetler, 2012; Evers, 2005; Ferlie, Fitzgerald, \& Pettigrew, 1996; Gans, 2008; Hall, Miller, \& Millar, 2016; Hancock \& Tyler, 2008; M. Parker, 2006; Pollitt \& Bouckaert, 2004).

The concept of hybridization has already had a significant impact on the general discourse on business and management and formed frequently discussed issues in the workplace. The phenomenon will continue to have an influence on business extensions (Goldoff, 2000; Rehn, 2008).

Public and non-profit organizations are increasingly expected to demonstrate positive results. Organizations with contractual obligations and social impact require the adoption of hybrid instruments. Many non-profit organizations and social enterprises now receive public funding for offering services that combine market income with public priorities (Garrow \& Hasenfeld, 2012; Kleynjans \& Hudon, 2016; S. R. Smith \& Phillips, 2016).

These social enterprises are often assessed based on their performance through indicators such as the placement of disadvantaged adults in employment. Yet, little consideration is given to social capital and community contributions from non-profit organizations. More attention needs to be paid to ways in which performance management strategies can measure non-profit impact in a more broadly defined sense. This would consequently help non-profit executives and board members to more effectively manage multiple institutional logics within the organization (Goldoff, 2000; Skelcher \& Smith, 2017). Research is needed to identify the best tools for companies to use that would satisfy the transparency, responsibility and the consequence of merging knowledge in the public, private and non-profit sectors (P. Biancone \& Secinaro, 2015; P. Biancone, Secinaro, \& Brescia, 2017; P. Biancone, Secinaro, Brescia, \& Iannaci, 2018a, 2018b; Brescia, 2019).

Hybridity can be regarded as a cause of innovation: multiple logics within an organization force the agency to restructure and develop new affiliations and subsidiaries in order to adequately cope with the governance and management imperatives of hybridity (Collings et al., 2008; Coule \& Patmore, 2013; Harhoff \& Mayrhofer, 2010; S. R. Smith, 2014; Torchia \& Calabrò, 2018).

\section{Discussion}

The increase of social influence on technology and of industrial restructuring has been negatively impacted by globalization. Today, as there are still many opportunities for multi-disciplinary research within science, such hybrid developments will continue to occur (Geana, 1997; Kraidy, 2017; Pieterse, 1994; Stanton, 2004; Stockhammer, 2012).

They are part of the inner dynamics of the social science system. There is evidence that while hybridization has been multi-disciplinary in the past, and related activities often co-occurred in different disciplines, this is no longer the case.

Disciplines are increasingly overlapping (Georghiou, 1998). To some extent this wider hybridization across disciplines seems to prompt by transfers of technically sophisticated instrumentation from one research field to another.

'Integration' works on many different levels, from the grass-roots measurement and monitoring of environmental degradation from local to national and international levels, to the inclusion of public representation in experimental consensus conferences and the inclusion of lay people on boards of environmental research institutions.

It is therefore not surprising that more recent technological systems like 'management systems', and the technically hybrid telematics systems of the information technology age, have come to espouse and express a different spirit altogether calling these non-grid based hybrid projects of the 1970s and 1980s 'post-modern' technologies (Hughes, Dwivedi, \& Rana, 2017). As a rule, they involve not only technical or engineering problems, but substantial political, social and environmental issues. What makes them different, from their pre-modern or modern predecessors, is how professional engineers approach the problems they encounter.

There is another effect of hybridization, this is the rise of hybrid fora. These hybrid fora are public spaces where risks associated with certain technological developments are debated. It is in these fora that new knowledge is generated. Other areas can also be identified where encounters between various political and social agencies with different interests and outlooks are made possible. Each of these carries' implications for the process of 
knowledge production. It is now recognized that new scientific concepts can be produced outside disciplinary structures, giving rise to changes in curricula and the transmission of scientific knowledge.

In some areas of research, for example, in the bio-medical field, this has become an important complementary source for how knowledge is produced and enriched. It is seen with equal importance to local, alternative and hybrid sources of knowledge production. Contextualization then becomes a multi-layered process, which does not necessarily attempt to strip down everything in a reductionist mode to one 'fundamental' level of explanation.

This paper also argues for a greater variety of knowledge traditions alongside the 'mainstream' Western Enlightenment tradition, one that is local, alternative or hybrid. It is local in the sense that it stands outside traditional learning. It is alternative in the sense of being, at times, actively opposed to traditional learning. It is hybrid in the sense of combining scientific and other knowledge elements, and therefore running the risk of being labeled 'impure' by traditional scientists (Koppel, 1999; Nowotny, Scott, Gibbons, \& Scott, 2001).

What emerges from the literature of hybrid organizations seen from the point of view of NPM, the concept of Paradox, PPPs and Hybrid Impact is very interesting because by tidying up the concepts that various scholars have found (Figure 3) it is possible to define what have been the factors that influenced the evolution of hybrid organizations giving a historical definition and helping to understand the roots of the concept and specifically where these new entities will generate impact.Several documents have analyzed the contribution of these approaches to the improvement of Management, Decision-Making, Identity Work, Governance, Hybrid Laws, MFIs and Corporatizing.

The current state of the phenomenon of hybridity has been tested with a logical methodological process to minimize waste by assuming responsibility in the choice of final articles.

Casini (2014) focuses on the multipolarity of the administrative law tand this greatly helps the understanding of hybrid organizations because despite he approaches the topic from the legislative point of view this method of reasoning applied in all other contexts can evolve towards the innovation of the concept of hybrid. The proliferation of relationships between different actors - namely agencies, corporations, non-governmental organizations (NGOs) and individuals, that currently dominate the panorama heighten the need for research into hybridity, particularly within global law and the crisis of legality, as generated by the growth of standardization activities beyond the state (Bozeman \& Moulton, 2011; Cassese, 2012). Hybridity is one of the factors that many articles cite as leading to globalization and its consequential effects (Carney, 2005; Deem, 2001; Gillespie, Mcbride, \& Riddle, 2010).

Although the selection of articles for research in this paper did not use a chronological filter, there were no results before 1998. Many scholars argue that the industrial age and post-war growth led to the emergence of hybridity through increased globalization.

Proponents of NPM expect public organizations to become more flexible and adaptive after administrative reforms, in effect, showing convergence with organizational change models in the private sector.

Statistical analysis shows that competition increases the impact of change in both public and private organizations. The high levels of managerial autonomy and exposure to regulatory pressures arose from an increased impact in a change in public organizations, but not in private organizations. Rather, the results support the idea that NPM reform made public organizations more like private organizations (Cuervo, Ribeiro, \& Roig, 2007; Nieto Morales et al., 2013; Schmidthuber \& Wiener, 2018).

The growing involvement of the private sector in the design and management of urban public space has prompted some critical scholars to foresee the "end of public space" (Langstraat \& Van Melik, 2013). A powerful mobilization movement seems to have been activated, which supports the growth of social entrepreneurs as agents of change (Hervieux \& Voltan, 2018).

Requests for non-profit organization activity are becoming more "business-like", and increasingly linking third party performance to the mission of companies (Cheverton, 2007). Hybridity has provided an alternative perspective to the search for charity positioning in the literature of marketing and contemporary strategy (Chew \& Osborne, 2009). 


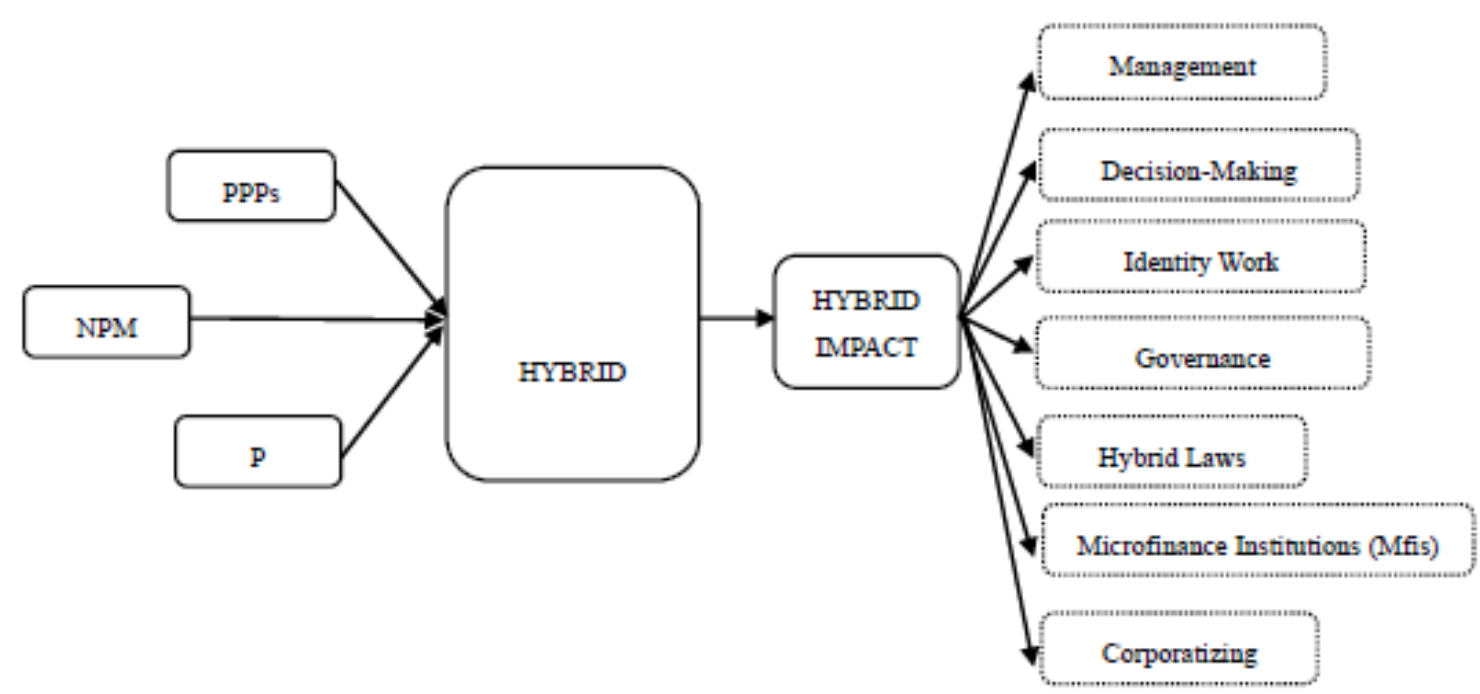

Figure 3. Evolution of the hybrid phenomenon

Source: Our production

\section{Conclusion}

Intending to answer the question "whether it is possible to analyze and map the evolution of hybrid organizations" the research finds that exist the factors that involved in the development of hybrid organizations.

This research has shown that the phenomenon of hybridity can be analyzed, so much so, that it is possible to be logically mapped. Developments that have taken place seem to have followed a well-defined path.

First, there is a growing interest in the subject and that often case studies are used as the empirical approach in a lot of research, with the intention of theorizing a phenomenon that researchers have previously noticed. Interestingly, a lot of research has been conducted on what it now calls "hybrid organizations" or "hybridity" without their ever referring to the term.

Secondly, it was noticed that whilst no chronological filter was used to select articles for inspection, the earliest article was from 1998. This may be due to the legislative influence of that period, especially in the United Kingdom, when the earliest academic research into hybridity was conducted in the late 1990s.

Through the in-depth study of this systematic approach to literature, it is possible to understand better the factors that have influenced the development of the concept of hybridity. Currently it is still in the evolutionary phase because there are theoretical frameworks and some case studies but there is a need for these identities to be considered by all the engine of social innovation and to operate them in the correct way it is necessary to understand them.

It is essential that the profit, non-profit and public world work together to really look at progress in social innovation through Change, Corporate Sustainability, Corporatizing, Decision-Making, Governance, Hybrid Laws, Identity Work, Impact Of Hybrid Laws, Management, Microfinance Institutions (Mfis), Organization, Performance, Privatization, Public Management and Public-Private Partnerships.

Through this research the authors hope to contribute to the academic and professional community by summarizing the known literature and suggesting paths for further research precisely because it is necessary that the academic and professional world goes in the same direction as to proceed towards new discoveries and a strong collaboration between the two is necessary.

\section{Conflict of Interest: The authors declare that they have no conflict of interest.}




\section{References}

Aagaard, P. (2016). How to Make the Mix Matter: A Case Study of Post-Transformational Leadership in Hybrid Public Management. International Journal of Public Administration, 39(14), 1171-1179. https://doi.org/10.1080/01900692.2015.1072211

Abdul-Aziz, A. R. (2012). Control mechanisms exercised in Malaysian housing public-private partnerships. Construction Management and Economics, 30(1), 37-55. https://doi.org/10.1080/01446193.2011.654129

Agranoff, R. (2007). Managing within networks: Adding value to public organizations. Georgetown University Press.

Alexius, S., Örnberg, J. C., \& Grossi, G. (2019). Logics and Practices of Board Appointments in Hybrid Organizations: The Case of Swedish State-Owned Enterprises. In Managing Hybrid Organizations (pp. 157-178). Springer. https://doi.org/10.1007/978-3-319-95486-8_8

Alvesson, M. (2010). Self-doubters, strugglers, storytellers, surfers and others: Images of self-identities in organization studies. Human Relations, 63(2), 193-217. https://doi.org/10.1177/0018726709350372

Aman, A. C. (2008). Politics, Policy and Outsourcing in the United States: The Role of Administrative Law.

Arquilla, J., \& Ronfeldt, D. (1997). In Athena's camp: Preparing for conflict in the information age. Rand corporation.

Barry, J., Berg, E., \& Chandler, J. (2006a). Academic Shape Shifting: Gender, Management and Identities in Sweden and England. Organization, 13(2), 275-298. https://doi.org/10.1177/1350508406061673

Barry, J., Berg, E., \& Chandler, J. (2006b). Movement and change in the public sector: Bringing social movements into the analysis. Public Management Review, 8(3), 433-448. https://doi.org/10.1080/14719030600853329

Bartocci, L., Grossi, G., \& Mauro, S. G. (2019). Towards a hybrid logic of participatory budgeting. International Journal of Public Sector Management, 32(1), 65-79. https://doi.org/10.1108/IJPSM-06-2017-0169

Beech, N., Gilmore, C., Hibbert, P., \& Ybema, S. (2016). Identity-in-the-work and musicians' struggles: The production of self-questioning identity work. Work, Employment and Society, 30(3), 506-522. https://doi.org/10.1177/0950017015620767

Bezes, P., Demazière, D., Le Bianic, T., Paradeise, C., Normand, R., Benamouzig, D., ... Evetts, J. (2011). New Public Management et professions dans l'État: Au-delà des oppositions, quelles recompositions? Sociologie du travail, 53(3), 293-348. https://doi.org/10.1016/j.soctra.2011.06.003

Biancone, P. P., \& Radwan, M. (2019). Social Finance and Financing Social Enterprises: An Islamic Finance Prospective. European Journal of Islamic Finance, O(0). https://doi.org/10.13135/2421-2172/3176

Biancone, P., \& Secinaro, S. (2015). Popular financial reporting: Un nuovo strumento di rendicontazione per le municipalità. Retrieved from https://iris.unito.it/handle/2318/1557120\#.WqkBkejOXIU

Biancone, P., Secinaro, S., \& Brescia, V. (2017). The Popular Financial Reporting and Gender Accountability, the Integrated Approach in Municipalities and Public Bodies. American International Journal of Contemporary Research, 7, 1-11.

Biancone, P., Secinaro, S., Brescia, V., \& Iannaci, D. (2018a). Communication and data processing in local public group: Transparency and accountability. International Journal of Business and Management, 13(10), 20-37. https://doi.org/10.5539/ijbm.v13n10p20

Biancone, P., Secinaro, S., Brescia, V., \& Iannaci, D. (2018b). Popular Financial Reporting, A New Information Tool For Social Cooperatives. Retrieved from https://iris.unito.it/handle/2318/1701273\#.XUBdGugzbIU

Billis, D. (2010). Hybrid organizations and the third sector: Challenges for practice, theory and policy. Macmillan International Higher Education.

Bird, M. G. (2015). Canadian state-owned enterprises: A framework for analyzing the evolving Crowns. Policy Studies, 36(2), 1-24. https://doi.org/10.1080/01442872.2014.1000843

Bode, I., Lange, J., \& Märker, M. (2017). Caught in organized ambivalence: Institutional complexity and its implications in the German hospital sector. Public Management Review, 19(4), 501-517. https://doi.org/10.1080/14719037.2016.1195437

Bozeman, B., \& Moulton, S. (2011). Integrative Publicness: A Framework for Public Management Strategy and 
Performance. Journal of Public Administration Research and Theory, 21(suppl3), i363-i380. https://doi.org/10.1093/jopart/mur031

Brescia, V. (2019). The popular financial reporting: New accounting tool for Italian municipalities (Vol. 1209). Franco Angeli.

Brown, A. D. (2015). Identities and identity work in organizations. International Journal of Management Reviews, 17(1), 20-40. https://doi.org/10.1111/ijmr.12035

Bryson, J. M., \& Roering, W. D. (1987). Applying private-sector strategic planning in the public sector. Journal of the American Planning Association, 53(1), 9-22. https://doi.org/10.1080/01944368708976631

Calderini, M., Chiodo, V., \& Michelucci, F. V. (2018). The social impact investment race: Toward an interpretative framework. European Business Review, 30(1), 66-81. https://doi.org/10.1108/EBR-10-2016-0134

Carney, M. (2005). Globalization and the Renewal of Asian Business Networks. Asia Pacific Journal of Management, 22(4), 337-354. https://doi.org/10.1007/s10490-005-4114-z

Carollo, L., \& Guerci, M. (2018). 'Activists in a Suit': Paradoxes and Metaphors in Sustainability Managers' Identity Work. Journal of Business Ethics, 148(2), 249-268. https://doi.org/10.1007/s10551-017-3582-7

Casini, L. (2014). "Down the rabbit-hole": The projection of the public/private distinction beyond the state. International Journal of Constitutional Law, 12(2), 402-428. https://doi.org/10.1093/icon/mou015

Cassese, S. (2012). New paths for administrative law: A manifesto. International Journal of Constitutional Law, 10(3), 603-613. https://doi.org/10.1093/icon/mos038

Chan, H. S., \& Chow, K. W. (2007). Public Management Policy and Practice in Western China: Metapolicy, Tacit Knowledge, and Implications for Management Innovation Transfer. The American Review of Public Administration, 37(4), 479-498. https://doi.org/10.1177/0275074006297552

Cheverton, J. (2007). Holding Our Own: Value and Performance in Nonprofit Organisations. Australian Journal of Social Issues, 42(3), 427-436, 286. https://doi.org/10.1002/j.1839-4655.2007.tb00068.x

Chew, C., \& Osborne, S. P. (2009). Identifying the Factors That Influence Positioning Strategy in U.K. Charitable Organizations That Provide Public Services: Toward an Integrating Model. Nonprofit and Voluntary Sector Quarterly, 38(1), 29-50. https://doi.org/10.1177/0899764008315180

Clarke, J., \& Newman, J. (1997). The managerial state: Power, politics and ideology in the remaking of social welfare. Sage.

Clegg, S. R., da Cunha, J. V., \& e Cunha, M. P. (2002). Management paradoxes: A relational view. Human Relations, 55(5), 483-503. https://doi.org/10.1177/0018726702555001

Collings, D. G., Gunnigle, P., \& Morley, M. J. (2008). Between Boston and Berlin: American MNCs and the shifting contours of industrial relations in Ireland. The International Journal of Human Resource Management, 19(2), 240-261. https://doi.org/10.1080/09585190701799812

Cooney, K. (2006). The institutional and technical structuring of nonprofit ventures: Case study of a US hybrid organization caught between two fields. Voluntas: International Journal of Voluntary and Nonprofit Organizations, 17(2), 137-155. https://doi.org/10.1007/s11266-006-9010-8

Cooper, D. J., \& Robson, K. (2006). Accounting, professions and regulation: Locating the sites of professionalization. Accounting, Organizations and Society, 31(4), 415-444. https://doi.org/10.1016/j.aos.2006.03.003

Cooper, J. (2003). Pride versus prejudice: Jewish doctors and lawyers in England, 1890-1990. Littman Library of Jewish Civilization, 451. https://doi.org/10.2307/j.ctv39x6kr

Corvo, L., \& Pastore, L. (2019). The challenge of Social Impact Bond: The state of the art of the Italian context. European Journal of Islamic Finance.

Coule, T., \& Patmore, B. (2013). Institutional Logics, Institutional Work, and Public Service Innovation in Non-Profit Organizations. Public Administration, 91(4), 980-997. https://doi.org/10.1111/padm.12005

Cuervo, Á., Ribeiro, D., \& Roig, S. (2007). Entrepreneurship: Concepts, Theory and Perspective. Introduction. In Á. Cuervo, D. Ribeiro, \& S. Roig (Eds.), Entrepreneurship: Concepts, Theory and Perspective (pp. 1-20). https://doi.org/10.1007/978-3-540-48543-8_1 
Curran, G. M., Bauer, M., Mittman, B., Pyne, J. M., \& Stetler, C. (2012). Effectiveness-implementation hybrid designs: Combining elements of clinical effectiveness and implementation research to enhance public health impact. Medical Care, 50(3), 217. https://doi.org/10.1097/MLR.0b013e3182408812

Deem, R. (1998). 'New managerialism' and higher education: The management of performances and cultures in universities in the United Kingdom. International Studies in Sociology of Education, 8(1), 47-70. https://doi.org/10.1080/0962021980020014

Deem, R. (2001). Globalisation, New Managerialism, Academic Capitalism and Entrepreneurialism in Universities: Is the local dimension still important? Comparative Education, 37(1), 7-20. "https://doi.org/10.1080/03050060020020408

Denyer, D., \& Tranfield, D. (2009). Producing a systematic review.

Durant, R. F. (2014). Progressivism, Corporate Capitalism, and the Social Sciences: Confronting the Paradox of Federal Administrative Reform in America. Administration \& Society, 46(6), 599-631. https://doi.org/10.1177/0095399713509244

Dyer, J. H., Powell, B. C., Sakakibara, M., \& Wang, A. J. (2007). THE DETERMINANTS OF SUCCESS IN R\&D ALLIANCES. Academy of Management Proceedings, 2007, 1-6. Academy of Management Briarcliff Manor, NY 10510. https://doi.org/10.5465/ambpp.2007.26508253

Evers, A. (2005). Mixed welfare systems and hybrid organizations: Changes in the governance and provision of social services. Intl Journal of Public Administration, 28(9-10), 737-748. https://doi.org/10.1081/PAD-200067318

Ferlie, E., Fitzgerald, L., \& Pettigrew, A. (1996). The new public management in action. OUP Oxford. https://doi.org/10.1093/acprof:oso/9780198289029.001.0001

Flinders, M. (2011). Devolution, delegation and the Westminster Model: A comparative analysis of developments within the UK, 1998-2009. Commonwealth \& Comparative Politics, 49(1), 1-28. https://doi.org/10.1080/14662043.2011.541109

Foljanty-Jost, G. (2011). Bringing the Citizen Back In: Democratic Dimensions of Local Reforms in Germany and Japan. East Asia, 28(4), 313-328. https://doi.org/10.1007/s12140-011-9157-9

Gans, H. (2008). Popular culture and high culture: An analysis and evaluation of taste. Basic Books.

Garrone, P., Grilli, L., \& Rousseau, X. (2013). Management Discretion and Political Interference in Municipal Enterprises. Evidence from Italian Utilities. Local Government Studies, 39(4), 514-540. https://doi.org/10.1080/03003930.2012.726198

Garrow, E., \& Hasenfeld, Y. (2012). Managing conflicting institutional logics: Social service versus market. In Social Enterprises (pp. 121-143). Springer. https://doi.org/10.1057/9781137035301_6

Geana, G. (1997). Ethnicity and globalisation. Outline of a complementarist conceptualisation. Social Anthropology, 5(2), 197-209. https://doi.org/10.1111/j.1469-8676.1997.tb00350.x

Georghiou, L. (1998). Global cooperation in research. Research Policy, 27(6), 611-626. https://doi.org/10.1016/S0048-7333(98)00054-7

Gillespie, K., Mcbride, J. B., \& Riddle, L. (2010). Globalization, Biculturalism and Cosmopolitanism: The Acculturation Status of Mexicans in Upper Management. International Journal of Cross Cultural Management, 10(1), 37-53. https://doi.org/10.1177/1470595809359581

Goldoff, A. C. (2000). Decision-making in organizations: The new paradigm. International Journal of Public Administration, 23(11), 2017-2044. https://doi.org/10.1080/01900690008525535

Gotsi, M., Andriopoulos, C., Lewis, M., \& Ingram, A. (2010). Creative workers: Managing tensions of multiple identities. Human Relations, 63(6), 781-805. https://doi.org/10.1177/0018726709342929

Green, M. (2009). Podium or participation? Analysing policy priorities under changing modes of sport governance in the United Kingdom. International Journal of Sport Policy and Politics, 1(2), 121-144. https://doi.org/10.1080/19406940902950697

Greenland, S., \& O'rourke, K. (2001). On the bias produced by quality scores in meta-analysis, and a hierarchical view of proposed solutions. Biostatistics, 2(4), 463-471.

https://doi.org/10.1093/biostatistics/2.4.463

Greve, C., \& Andersen, K. V. (2001). Management of telecommunications service provision: An analysis of the 
Tele Denmark company 1990-8. Public Management Review, 3(1), 35-52. https://doi.org/10.1080/14616670010009441

Grimsey, D., \& Lewis, M. K. (2002). Evaluating the risks of public private partnerships for infrastructure projects. International Journal of Project Management, 20(2), 107-118. https://doi.org/10.1016/S0263-7863(00)00040-5

Grossi, G., \& Thomasson, A. (2015). Bridging the accountability gap in hybrid organizations: The case of Copenhagen Malmö Port. International Review of Administrative Sciences, 81(3), 604-620. https://doi.org/10.1177/0020852314548151

Hahn, T., Figge, F., Pinkse, J., \& Preuss, L. (2018). A Paradox Perspective on Corporate Sustainability: Descriptive, Instrumental, and Normative Aspects. Journal of Business Ethics, 148(2), 235-248. https://doi.org/10.1007/s10551-017-3587-2

Hall, K., Miller, R., \& Millar, R. (2016). Public, Private or Neither? Analysing the publicness of health care social enterprises. Public Management Review, 18(4), 539-557. https://doi.org/10.1080/14719037.2015.1014398

Hancock, P., \& Tyler, M. (2008). Beyond the Confines: Management, Colonization and the Everyday. Critical Sociology, 34(1), 29-49. https://doi.org/10.1177/0896920507084622

Harhoff, D., \& Mayrhofer, P. (2010). Managing User Communities and Hybrid Innovation Processes: Concepts and Design Implications. Organizational Dynamics, 39(2), 137-144. https://doi.org/10.1016/j.orgdyn.2010.01.005

Hart, O. (2003). Incomplete contracts and public ownership: Remarks, and an application to public-private partnerships. The Economic Journal, 113(486), C69-C76. https://doi.org/10.1111/1468-0297.00119

Hasenfeld, Y., \& Gidron, B. (2005). Understanding multi-purpose hybrid voluntary organizations: The contributions of theories on civil society, social movements and non-profit organizations. Journal of Civil Society, 1(2), 97-112. https://doi.org/10.1080/17448680500337350

Herranz, J. J. (2007). The multisectoral trilemma of network management. Journal of Public Administration Research and Theory, 18(1), 1-31. https://doi.org/10.1093/jopart/mum004

Hervieux, C., \& Voltan, A. (2018). Framing Social Problems in Social Entrepreneurship. Journal of Business Ethics, 151(2), 279-293. https://doi.org/10.1007/s10551-016-3252-1

Hodge, G. A. (2004). The risky business of public-private partnerships. Australian Journal of Public Administration, 63(4), 37-49. https://doi.org/10.1111/j.1467-8500.2004.00400.x

Hodge, G. A., \& Greve, C. (2007). Public-private partnerships: An international performance review. Public Administration Review, 67(3), 545-558. https://doi.org/10.1111/j.1540-6210.2007.00736.x

Hodge, G. A., Greve, C., \& Boardman, A. E. (2010). Introduction: The PPP phenomenon and its evaluation. Chapters. https://doi.org/10.4337/9781849804691.00008

Hughes, D. L., Dwivedi, Y. K., \& Rana, N. P. (2017). Mapping IS failure factors on PRINCE2® stages: An application of Interpretive Ranking Process (IRP). Production Planning \& Control, 28(9), 776-790. https://doi.org/10.1080/09537287.2017.1311431

Huuskonen, A., \& Kourula, A. (2012). Network management: A review of an emerging cross-disciplinary field. 28th IMP-Conference in Rome, Italy in 2012.

Huxham, C., \& Beech, N. (2003). Contrary prescriptions: Recognizing good practice tensions in management. Organization Studies, 24(1), 69-93. https://doi.org/10.1177/0170840603024001678

Itzin, C., \& Newman, J. (1995). Gender, culture and organizational change: Putting theory into practice. Psychology Press.

Kannothra, C., Manning, S., \& Haigh, N. (2018). How Hybrids Manage Growth and Social-Business Tensions in Global Supply Chains: The Case of Impact Sourcing. Journal of Business Ethics, 148(2), 271-290. https://doi.org/10.1007/s10551-017-3585-4

Kickert, W. J. (2003). Beyond public management: Shifting frames of reference in administrative reforms in The Netherlands. Public Management Review, 5(3), 377-399. https://doi.org/10.1080/1471903032000146955

Kinder, T. (2012). Learning, Innovating and Performance in Post-New Public Management of Locally Delivered Public Services. Public Management Review, 14(3), 403-428. 
https://doi.org/10.1080/14719037.2011.637408

Kirkpatrick, I., Altanlar, A., \& Veronesi, G. (2017). Corporatisation and the Emergence of (Under-Managered) Managed Organisations: The Case of English Public Hospitals. Organization Studies, 38(12), 1687-1708. https://doi.org/10.1177/0170840617693273

Kirkpatrick, I., Kuhlmann, E., Hartley, K., Dent, M., \& Lega, F. (2016). Medicine and management in European hospitals: A comparative overview. BMC Health Services Research, 16(Suppl 2). https://doi.org/10.1186/s12913-016-1388-4

Kleynjans, L., \& Hudon, M. (2016). A Study of Codes of Ethics for Mexican Microfinance Institutions. Journal of Business Ethics, 134(3), 397-412. https://doi.org/10.1007/s10551-014-2434-y

Klijn, E. H., \& Teisman, G. R. (2003). Institutional and Strategic Barriers to Public-Private Partnership: An Analysis of Dutch Cases. Public Money \& Management, 23(3), 137-146. https://doi.org/10.1111/1467-9302.00361

Kliksberg, B. (2005). Public administration in Latin America: Promises, frustrations and new examinations. International Review of Administrative Sciences, 71(2), 309-326. https://doi.org/10.1177/0020852305053889

König, K. (2003). On the typology of public administration. International Review of Administrative Sciences, 69(4), 449-462. https://doi.org/10.1177/0020852303694002

Koppel, J. G. S. (1999). The Challenge of Administration by Regulation: Preliminary Findings Regarding the U.S. Government's Venture Capital Funds. Journal of Public Administration Research and Theory, 9(4), 641-666. https://doi.org/10.1093/oxfordjournals.jpart.a024426

Kraidy, M. (2017). Hybridity, or the cultural logic of globalization. Temple University Press.

Lähdesmäki, M. (2012). Construction of owner-manager identity in corporate social responsibility discourse. Business Ethics: A European Review, 21(2), 168-182. https://doi.org/10.1111/j.1467-8608.2011.01644.x

Lan, Z., \& Hal, G. R. (1992). Goals, Rules, and Effectiveness in Public, Private, and Hybrid Organizations: More Evidence on Frequent Assertions About Differences. Journal of Public Administration Research and Theory. https://doi.org/10.1093/oxfordjournals.jpart.a037111

Langstraat, F., \& Van Melik, R. (2013). Challenging the 'End of Public Space': A Comparative Analysis of Publicness in British and Dutch Urban Spaces. Journal of Urban Design, 18(3), 429-448. https://doi.org/10.1080/13574809.2013.800451

Langton, S. (1987). Envoi: Developing nonprofit theory. Journal of Voluntary Action Research, 16(1-2), 134-148. https://doi.org/10.1177/089976408701600111

Lewis, M. W. (2000). Exploring paradox: Toward a more comprehensive guide. Academy of Management Review, 25(4), 760-776. https://doi.org/10.5465/amr.2000.3707712

Linder, S. H. (1999). Coming to terms with the public-private partnership: A grammar of multiple meanings. American Behavioral Scientist, 43(1), 35-51. https://doi.org/10.1177/00027649921955146

Lindlbauer, I., Winter, V., \& Schreyögg, J. (2016). Antecedents and Consequences of Corporatization: An Empirical Analysis of German Public Hospitals. Journal Of Public Administration Research And Theory, 26(2), 309-326. https://doi.org/10.1093/jopart/muv016

Lipsey, M. W., \& Wilson, D. B. (2001). Practical meta-analysis. Sage Publications, Inc.

Littell, J. H., Corcoran, J., \& Pillai, V. (2009). Systematic Reviews and Meta-Analysis (Vol. 9780195326543). https://doi.org/10.1093/acprof:oso/9780195326543.001.0001

Lockwood, M., \& Davidson, J. (2010). Environmental governance and the hybrid regime of Australian natural resource management. Geoforum, 41(3), 388-398. https://doi.org/10.1016/j.geoforum.2009.12.001

Mac Amhlaigh, C., Michelon, C., \& Walker, N. (2013). After public law. OUP Oxford. https://doi.org/10.1093/acprof:oso/9780199669318.001.0001

Maccarthaigh, M. (2012). Politics, Policy Preferences and the Evolution of Irish Bureaucracy: A Framework for Analysis. Irish Political Studies, 27(1), 23-47. https://doi.org/10.1080/07907184.2012.636180

Manning, N. (2001). The legacy of the New Public Management in developing countries. International Review of Administrative Sciences, 67(2), 297-312. https://doi.org/10.1177/0020852301672009 
Marquis, C., \& Battilana, J. (2009). Acting globally but thinking locally? The enduring influence of local communities on organizations. Research in Organizational Behavior, 29, 283-302. https://doi.org/10.1016/j.riob.2009.06.001

McLaughlin, J. C. A. C. E. (1994). Managing social policy. Sage.

Mele, V., \& Belardinelli, P. (2018). Mixed Methods in Public Administration Research: Selecting, Sequencing, and Connecting. Journal of Public Administration Research and Theory. https://doi.org/10.1093/jopart/muy046

Melián-González, S., \& Bulchand-Gidumal, J. (2009). Good moves, mistakes and unexpected events in an initiative to improve public management in the ICT service provision at a university. International Review of Administrative Sciences, 75(2), 271-291. https://doi.org/10.1177/0020852309104176

Meyer, R. E., \& Hammerschmid, G. (2006). Changing Institutional Logics and Executive Identities: A Managerial Challenge to Public Administration in Austria. American Behavioral Scientist, 49(7), 1000-1014. https://doi.org/10.1177/0002764205285182

Nieto Morales, F., Wittek, R., \& Heyse, L. (2013). After the Reform: Change in Dutch Public and Private Organizations. Journal of Public Administration Research And Theory, 23(3), 735-754. https://doi.org/10.1093/jopart/mus006

Norman, D. J. (2014). From shouting to counting: Civil society and good governance reform in Cambodia. The Pacific Review, 1-24. https://doi.org/10.1080/09512748.2014.882393

Nowotny, H., Scott, P., Gibbons, M., \& Scott, P. B. (2001). Re-thinking science: Knowledge and the public in an age of uncertainty. SciELO Argentina.

Parker, L. (2011). University corporatisation: Driving redefinition. Critical Perspectives on Accounting, 22(4), 434-450. https://doi.org/10.1016/j.cpa.2010.11.002

Parker, M. (2006). The counter culture of organisation: Towards a cultural studies of representations of work. Consumption, Markets and Culture, 9(1), 1-15. https://doi.org/10.1080/10253860500481338

Perry, J. L., \& Rainey, H. G. (1988). The public-private distinction in organization theory: A critique and research strategy. Academy of Management Review, 13(2), 182-201. https://doi.org/10.5465/amr.1988.4306858

Pestoff, V. (2004). The development and future of the social economy in sweden. Retrieved from https://www.scopus.com/inward/record.uri?eid=2-s2.0-84881703491\&partnerID=40\&md5=e699544a18bf6 55 eaf3a3ab0b8cbdba3

Phillips, M. (2013). On being green and being enterprising: Narrative and the ecopreneurial self. Organization, 20(6), 794-817. https://doi.org/10.1177/1350508412455084

Pieterse, J. N. (1994). Globalisation as hybridisation. International Sociology, 9(2), 161-184. https://doi.org/10.1177/026858094009002003

Pollitt, C., \& Bouckaert, G. (2004). Public management reform: A comparative analysis. Oxford University Press, USA.

Poole, M. S., \& Van de Ven, A. H. (1989). Using paradox to build management and organization theories. Academy of Management Review, 14(4), 562-578. https://doi.org/10.5465/amr.1989.4308389

Powell, C. (2003). The Delphi technique: Myths and realities. Journal of Advanced Nursing. https://doi.org/10.1046/j.1365-2648.2003.02537.x

Ratner, H. (2012). 'It Was The Night Of The Long Knives': When public management collides with group identities. Public Management Review, 14(1), 23-40. https://doi.org/10.1080/14719037.2011.589612

Rayner, J., Lawton, A., \& Williams, H. (2012). Organizational Citizenship Behavior and the Public Service Ethos: Whither the Organization? Journal of Business Ethics, 106(2), 117-130. https://doi.org/10.1007/s10551-011-0991-x

Reed, M., \& Anthony, P. (1993). Between an ideological rock and an organizational hard place: NHS management in the 1980s and 1990s. The Political Economy of Privatization. London: Routledge, 185-204.

Rehn, A. (2008). Pop (Culture) Goes the Organization: On Highbrow, Lowbrow and Hybrids in Studying Popular Culture Within Organization Studies. Organization, 15(5), 765-783. https://doi.org/10.1177/1350508408093652 
Rittel, H. W., \& Webber, M. M. (1973). Dilemmas in a general theory of planning. Policy Sciences, 4(2), 155-169. https://doi.org/10.1007/BF01405730

Roehrich, J. K., Lewis, M. A., \& George, G. (2014). Are Public-Private Partnerships a Healthy Option? A Systematic Review. Social Science and Medicine, 113, 110-119. https://doi.org/10.1016/j.socscimed.2014.03.037

Rosenthal, R. (1979). The file drawer problem and tolerance for null results. Psychological Bulletin, 86(3), 638. https://doi.org/10.1037/0033-2909.86.3.638

Roundy, P. T. (2017). Hybrid organizations and the logics of entrepreneurial ecosystems. International Entrepreneurship and Management Journal, 13(4), 1221-1237. https://doi.org/10.1007/s11365-017-0452-9

Sand, I. J. G. (2013). the transcendence of the public/private divide: What is Public Law under conditions of globalization. After Public Law. Oxford: Oxford University Press. https://doi.org/10.1093/acprof:oso/9780199669318.003.0010

Savas, E. S. (2000). Privatization and public-private partnerships.

Saz-Carranza, A., \& Longo, F. (2012). Managing Competing Institutional Logics in Public-Private Joint Ventures. Public Management Review, 14(3), 331-357. https://doi.org/10.1080/14719037.2011.637407

Schmidthuber, L., \& Wiener, M. (2018). Aiming for a sustainable future: Conceptualizing public open foresight. Public Management Review, 20(1), 82-107. https://doi.org/10.1080/14719037.2017.1293145

Schmitt, C. (2014). The Employment Effects of Privatizing Public Utilities in OECD Countries. Public Management Review, 16(8), 1164-1183. https://doi.org/10.1080/14719037.2013.792379

Schultz, C., Schreyoegg, J., \& Von Reitzenstein, C. (2013). The moderating role of internal and external resources on the performance effect of multitasking: Evidence from the R\&amp;D performance of surgeons. Research Policy, 42(8), 1356-1365. https://doi.org/10.1016/j.respol.2013.04.008

Simonet, D. (2015). Post-NPM Reforms or Administrative Hybridization in the French Health Care System? International Journal of Public Administration, 38(9), 1-10. https://doi.org/10.1080/01900692.2014.955195

Skelcher, C., \& Smith, S. R. (2017). New development: Performance promises and pitfalls in hybrid organizations-five challenges for managers and researchers. Public Money \& Management, 37(6), 425-430. https://doi.org/10.1080/09540962.2017.1344023

Smith, S. R. (2014). Hybridity and nonprofit organizations: The research agenda. American Behavioral Scientist, 58(11), 1494-1508. https://doi.org/10.1177/0002764214534675

Smith, S. R., \& Phillips, S. D. (2016). The changing and challenging environment of nonprofit human services: Implications for governance and program implementation. Nonprofit Policy Forum, 7, 63-76. De Gruyter. https://doi.org/10.1515/npf-2015-0039

Smith, W. K., \& Lewis, M. W. (2011). Toward a theory of paradox: A dynamic equilibrium model of organizing. Academy of Management Review, 36(2), 381-403. https://doi.org/10.5465/AMR.2011.59330958

Stanton, T. H. (2004). When Government Isn't Exactly Government. Jonathan G. S. Koppell. 2003. The Politics of Quasi-Government: Hybrid Organizations and the Dynamics of Bureaucratic Control. Cambridge, England: Cambridge University Press. 254 pp. Journal of Public Administration Research and Theory, 14(3), 435-437. https://doi.org/10.1093/jopart/muh027

Stockhammer, P. W. (2012). Questioning hybridity. In Conceptualizing Cultural Hybridization (pp. 1-3). Springer. https://doi.org/10.1007/978-3-642-21846-0_1

Street, C. T., \& Gallupe, R. B. (2009). A Proposal for Operationalizing the Pace and Scope of Organizational Change in Management Studies. Organizational Research Methods, 12(4), 720-737. https://doi.org/10.1177/1094428108327881

Sturdy, A., \& Wright, C. (2008). A Consulting Diaspora? Enterprising Selves as Agents of Enterprise. Organization, 15(3), 427-444. https://doi.org/10.1177/1350508408088538

Sveningsson, S., \& Alvesson, M. (2003). Managing managerial identities: Organizational fragmentation, discourse and identity struggle. Human Relations, 56(10), 1163-1193. https://doi.org/10.1177/00187267035610001

Teisman, G. R., \& Klijn, E. H. (2002). Partnership arrangements: Governmental rhetoric or governance scheme? Public Administration Review, 62(2), 197-205. https://doi.org/10.1111/0033-3352.00170 
Torchia, M., \& Calabrò, A. (2018). Increasing the Governance Standards of Public-Private Partnerships in Healthcare. Evidence from Italy. Public Organization Review, 18(1), 93-110. https://doi.org/10.1007/s11115-016-0363-1

Van der Byl, C. A., \& Slawinski, N. (2015). Embracing tensions in corporate sustainability: A review of research from win-wins and trade-offs to paradoxes and beyond. Organization \& Environment, 28(1), 54-79. https://doi.org/10.1177/1086026615575047

Wall, A., \& Connolly, C. (2009). The Private Finance Initiative: An Evolving Research Agenda? Public Management Review, 11(5), 707-724. https://doi.org/10.1080/14719030902798172

Watson, T. J. (2008). Managing identity: Identity work, personal predicaments and structural circumstances. Organization, 15(1), 121-143. https://doi.org/10.1177/1350508407084488

Williamson, O. E. (1985). Yhe Economic Institutions of Capitalism: Firms, markets, relational Contracting. Free Press.

Wong, E. L., Yeoh, E., Chau, P. Y., Yam, C. H., Cheung, A. W., \& Fung, H. (2015). How shall we examine and learn about public-private partnerships (PPPs) in the health sector? Realist evaluation of PPPs in Hong Kong. Social Science \& Medicine, 147, 261-269. https://doi.org/10.1016/j.socscimed.2015.11.012

\section{Appendix}

The following abbreviations are used in this study:

CS

CSOs

$\mathrm{E}$

$\mathrm{HI}$

LR

MFIs

NPM

$\mathrm{P}$

PPPs

\section{Case Study;}

Civil Society Organisations;

Exploration;

Hybrid Impact;

Literature Review;

Microfinance Institutions;

New Public Management;

Paradox;

Public-Private Partnerships; and

Survey.

\section{Copyrights}

Copyright for this article is retained by the author(s), with first publication rights granted to the journal.

This is an open-access article distributed under the terms and conditions of the Creative Commons Attribution license (http://creativecommons.org/licenses/by/4.0/). 